\title{
Coexistence of autoimmune hepatitis with extramedullary plasmacytoma
}

\author{
Ekstramedullar plazmasitom ile otoimmun hepatit birlikteliği
}

\author{
Adil Coşkun*, Serkan Borazan*, Özden Yükselen ${ }^{* * *}$, Irfan Yavaşoğlu ${ }^{* *}$, Mehmet Hadi Yaşa*, \\ Ali Önder Karaoğlu*
}

*Adnan Menderes Üniversitesi Tıp Fakültesi, İ̧ Hastalıkları AD, Gastroenteroloji Bölümü, Aydın

${ }^{* *}$ Adnan Menderes Üniversitesi Tıp Fakültesi, Iç Hastalıkları AD, Hematoloji Bölümü, Aydın

${ }^{* * *}$ Adnan Menderes Üniversitesi Tıp Fakültesi, lç Hastalıkları AD, Patoloji Bölümü, Aydın

\begin{abstract}
We present here a case with coexistence of extramedullary plasmacytoma (EMP) and Autoimmune hepatitis $(\mathrm{AH})$, in the pathogenesis of which there is mononuclear cell infiltration including plasma cells, and hyperimmunoglobulinemia which is characterized particularly with an increase in IgG.
\end{abstract}

Pam Med J 2015;8(3):243-246

Key words: Autoimmune hepatitis, Extramedullary plasmacytoma.

\section{Özet}

Burada, patogenezinde plazma hücrelerini de içeren mononükleer hücre infiltrasyonu ve özellikle lgG artışı ile karakterize hipergamaglobulineminin yer aldığı ekstramedullar plazmositom ve otoimmun hepatit birlikteliğini konu alan bir olgu sunmaktayız.

Pam Tıp Derg 2015;8(3):243-246

Anahtar sözcükler: Otoimmun hepatit, Ekstramedullar plazmasitom.

\section{Introduction}

Extramedullary plasmacytoma (EMP) is a rare clonal plasma cell tumor with an incidence rate of $3 / 100.000$ in community, and is detected $80 \%$ in the head and neck region. EMP accounts for $1 \%$ of all head and neck tumors [1-3]. Autoimmune hepatitis $(\mathrm{AH})$ is an inflammatory disease with an incidence of 1.6/100.000 in the community, and characterized by hypergammaglobulinemia and presence of specific autoantibodies in serum, and is more commonly encountered among women [4,5]. We present here a case with coexistence of $\mathrm{EMP}$ and $\mathrm{AH}$, in the pathogenesis of which there is mononuclear cell infiltration including plasma cells and hyperimmunoglobulinemia which is characterized particularly with an increase in lgG. To our knowledge, it has not been reported previously in the literature.

\section{Case}

A fifty-nine-year-old female patient was admitted with nasal congestion complaints. A nasopharyngeal mass was detected, and a biopsy was performed. Kappa and CD 138 positive stained cells were interpreted as plasmacytoma (Figure 1). On physical examination, liver and spleen was 2 and 3 $\mathrm{cm}$ below the costal margin, respectively. Laboratory evaluation, revealed ALT: $60 \mathrm{U} / \mathrm{L}$ (normal: 0-55); AST: $114 \mathrm{U} / \mathrm{L}$ (normal: 9-36); ALP: 174 U/L (normal: 40-150); GGT: 596 U/L (normal 125-243); LDH: 513 U/L (normal: 125$243 \mathrm{U} / \mathrm{L}$ ); total protein: $8.7 \mathrm{~g} / \mathrm{dL}$; globulin: 4.3 $\mathrm{g} / \mathrm{dL}$. Prothrombin time and complete blood evaluation was normal. Sedimentation rate was $36 \mathrm{~mm} / \mathrm{h}$. Anti-nuclear antibody (ANA) was positive at $1 / 320$ with a homogeneous pattern; anti-mitochondrial antibodies (AMA)

Adil Coşkun

Yazışma Adresi: Adnan Menderes Üniversitesi Tıp Fakültesi, İç Hastalıkları AD, Gastroenteroloji Bölümü, Aydın e-mail: adilcoskun@gmail.com 
and anti-smooth muscle antibody (ASMA) were negative. Immunoglobulin count: Ig (immunoglobulin) G 1938 mg/dL, IgA 598 mg/ dL. Her HBsAg was negative, anti-HBs was positive, anti-HCV was negative. Doppler ultrasonography of the portal system was normal. Urine immunoelectrophoresis was normal. Polyclonal increase was detected in serum immunoelectrophoresis. Bone marrow evaluation was within normal limits. Aliver biopsy revealed mononuclear cell infiltration which also includes plasma cells, and mixed staining with CD 138, kappa and lambda (Figure 1).
Whole-body positron emission tomography / computed tomography (PET/CT) evaluation of the patient was normal, except for pathological fluorodeoxyglucose (FDG) involvement with a standard uptake (SUV) of max 19.7 in the $27 \times 14.4 \mathrm{~mm}$-mass lesion in nasopharynx. (Figure 2). Polyclonal immunoelectrophoretic pattern, hepatitis markers, negative AMA and ASMA tests, positive ANA specified at 1/320 with a homogeneous pattern, and mononuclear cell infiltration including plasma cells, and staining with CD 138 and kappa detected in liver biopsy were all compiled and evaluated

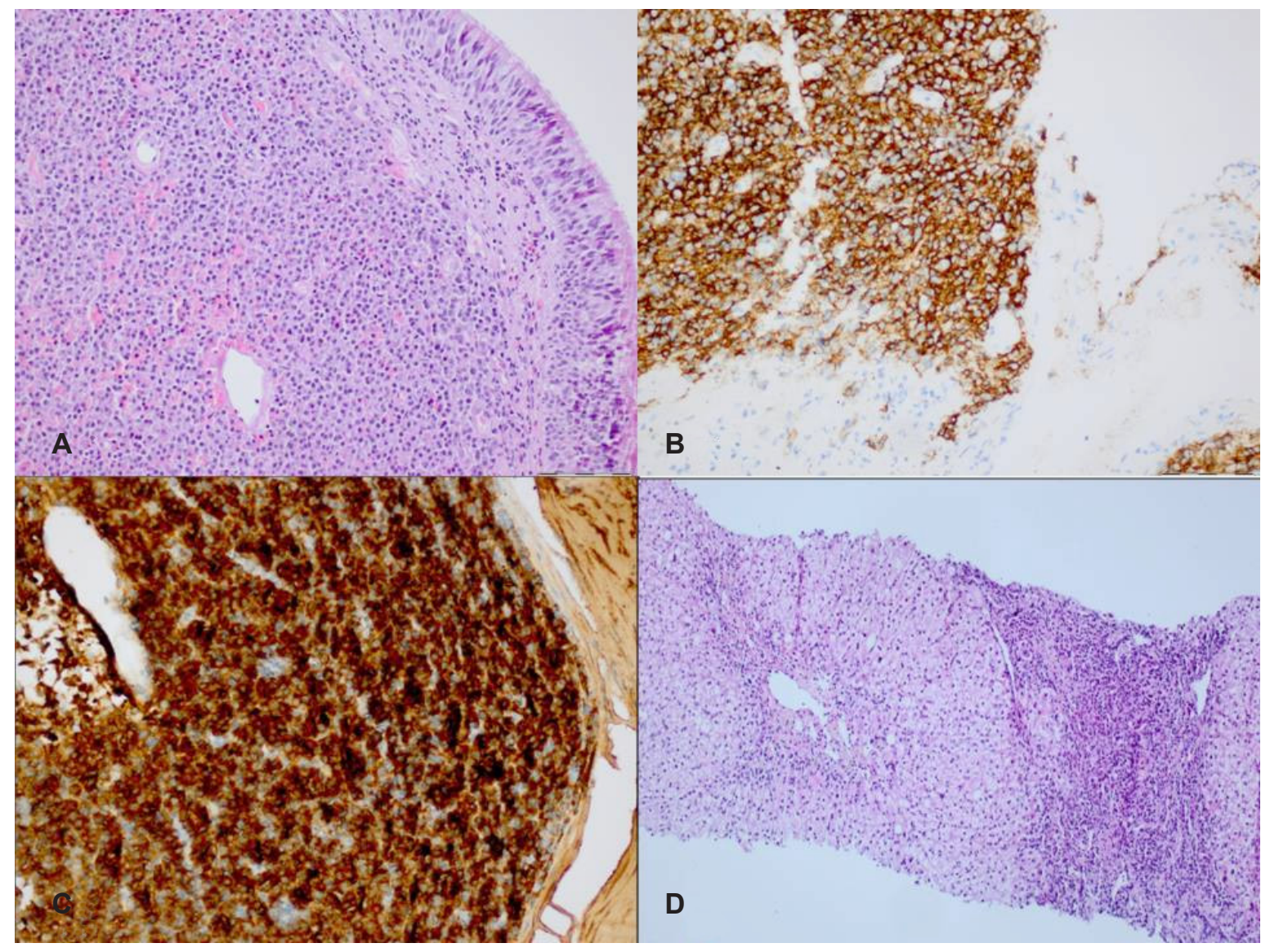

Figure 1. Nasopharynx and liver biopsy images. A. Diffuse plasmocytes observed in the nasopharynx (Hematoxylin-Eosin stain, x10 magnification), B. Nasopharyngeal plasmocytes diffusely stained with CD138 (x10 magnification), C. Plasmocytes stained with immunohistochemical Kappa (x10 magnifications), D. Infiltration of mononuclear cells, including plasma cells, in cirrhotic liver tissue (Hematoxylin-Eosin stain, x40 magnification).

and the patient was also diagnosed with Type 1 autoimmune hepatitis [4]. She was scheduled for radiotherapy for EMP, and corticosteroid therapy for autoimmune hepatitis. Following corticosteroid treatment, her liver function tests returned to normal, and plasmocytoma was not observed in the control PET/CT scanning after radiation therapy (Figure 2). The patient is currently in follow up in regard to both diseases. 

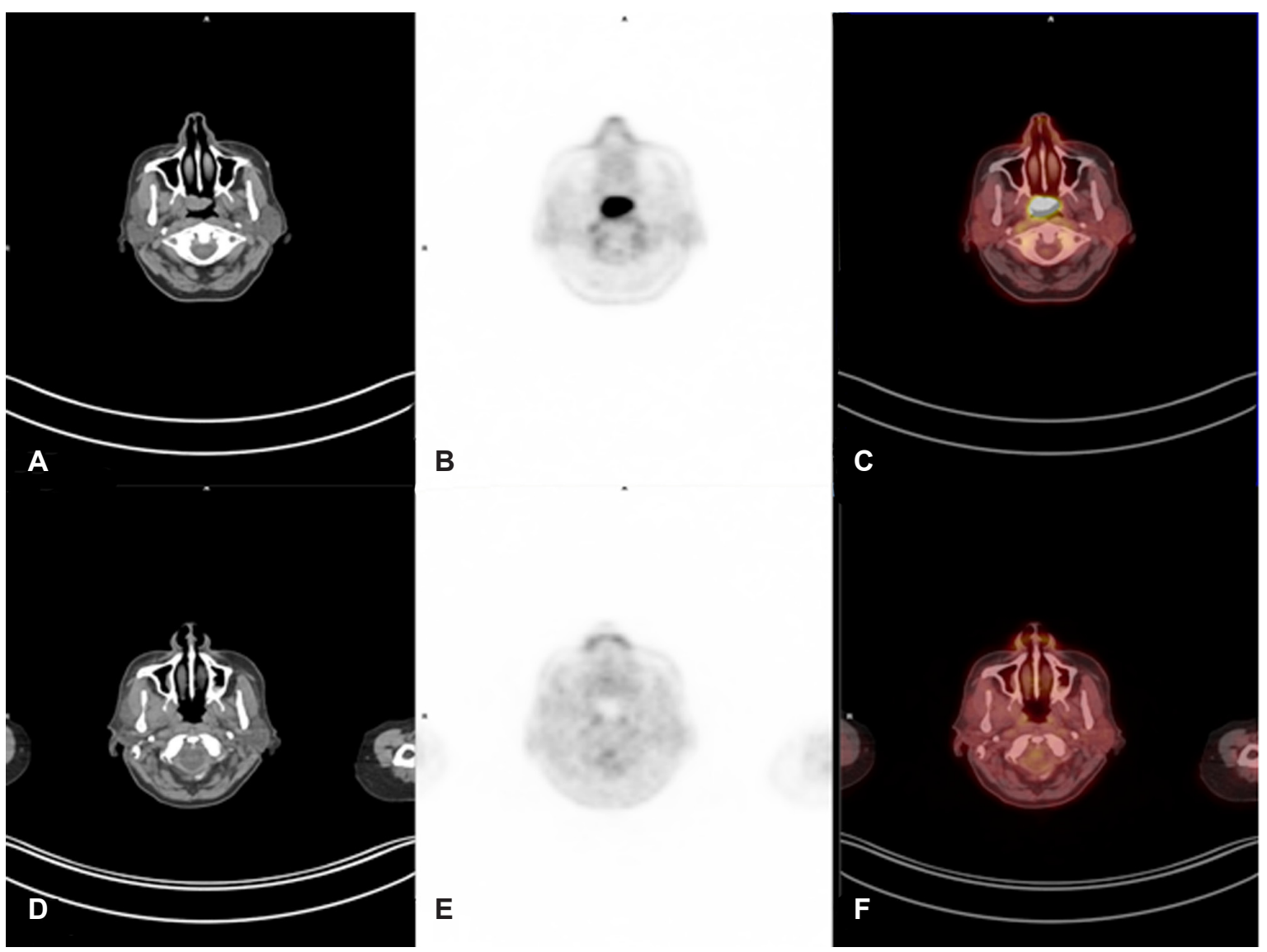

Figure 2. CT, PET and PET/CT fusion images before and after treatment. A. CT image of nasopharyngeal lesion identified at diagnosis B. PET image of nasopharyngeal lesion identified at diagnosis C. PET/CT image of nasopharyngeal lesion identified at diagnosis D. CT image of nasopharyngeal lesion after treatment E. PET image of nasopharyngeal lesion after treatment F. PET/CT image of nasopharyngeal lesion after treatment

\section{Discussion}

EMP, is a very rare clonal plasma cell tumor, characterized by absence of $\mathrm{M}$ protein in serum and urine, normal bone marrow, no evidence of end-organ damage, including bone, and is frequently localized in upper respiratory tract $[1,2]$. EMP localized in the nasal cavity can cause symptoms such as nasal congestion, rhinorrhea, and epistaxis [6]. $\mathrm{AH}$ is a rare inflammatory disease of unknown cause, characterized by hypergammaglobulinemia and presence of specific autoantibodies in serum, particularly involving periportal areas [4]. $\mathrm{AH}$ symptoms are nonspecific. Symptoms such as weakness, fatigue, jaundice, abdominal pain, nausea and vomiting can be observed; and sometimes asymptomatic cases can be detected while examining for abnormal liver function tests [7]. Several mechanisms have been proposed to explain hepatocyte injury in $\mathrm{AH}$. According to the most widely supported scientific hypothesis, in antibody-dependent cell mediated cytotoxicity, there is a defect in the suppression of Ig production. Uncontrolled production of $\mathrm{IgG}$ results in binding of $\mathrm{IgG}$ aggregates on the surface of hepatocytes on normal membrane components. These aggregate target natural killer cells and subsequent cytolysis occurs $[4,8]$. The increase of unexplained activation of plasma cells, autoimmune antibodies and in particular IgG along with hypergammaglobulinemia were determined to be the cause of liver damage in $\mathrm{AH}$, hence this suggests that EMP, a clonal plasma cell disease, might play a role in the pathophysiology of $\mathrm{AH}$. However this assumption is difficult to prove via a single case only. Therefore large autoimmune hepatitis or plasmocytoma series are required. Polyclonal immunoelectrophoretic pattern of the patient was correlated with autoimmune hepatitis. In this case, by presenting coexistence of EMP which was detected in nasopharynx while investigating nasal congestion complaints, 
and $\mathrm{AH}$ which was identified while examining abnormal liver function tests, we aimed to point out that plasma cell diseases may coexist with autoimmune diseases concomitantly in consequence of immune disorders.

Conflict of interest: We do not have any conflict of interest.

\section{References}

1. Grover N, Chary G, Makhija P, Rout P. Extramedullary plasmacytoma of the nasal cavity: treatment perspective in a developing nation. Ear Nose Throat $\mathrm{J}$ 2006;85:434-436.

2. Lomeo PE, McDonald JE, Finneman J, Shoreline. Extramedullary plasmacytoma of the nasal sinus cavities. Am J Otolaryngol 2007;28:50-51.

3. Gerry D, Lentsch EJ. Epidemiologic evidence of superior outcomes for extramedullary plasmacytoma of the head and neck. Otolaryngol Head Neck Surg 2013;148:974-981.

4. Krawitt EL. Autoimmune hepatitis. N Engl J Med 2006;354:54-66.

5. Grønbæk L, Vilstrup H, Jepsen P. Autoimmune hepatitis in Denmark: incidence,prevalence, prognosis, and causes of death. A nationwide registry-based cohort study. J Hepatol 2014;60:612-617.

6. Bachar G, Goldstein D, Brown D, et al. Solitary extramedullary plasmacytoma of the head and necklong-term outcome analysis of 68 cases. Head Neck 2008;30:1012-1019.

7. Makol A, Watt KD, Chowdhary VR. Autoimmune hepatitis: a review of current diagnosis and treatment. Hepat Res Treat 2011; 2011.

8. Francque S, Vonghia L, Ramon A, Michielsen P. Epidemiology and treatment of autoimmune hepatitis. Hepat Med 2012;4:1-10. 